\title{
HSTC Bulletin
}

Journal of the History of Canadian Science, Technology and Medecine

Revue d'histoire des sciences, des techniques et de la médecine au Canada

\section{Donors to the Cause}

Volume 3, numéro 4 (12), august 1979

URI : https://id.erudit.org/iderudit/1081881ar

DOI : https://doi.org/10.7202/1081881ar

Aller au sommaire du numéro

Éditeur(s)

HSTC Publications

ISSN

0228-0086 (imprimé)

1918-7742 (numérique)

Découvrir la revue

Citer ce document

(1979). Donors to the Cause. HSTC Bulletin, 3(4), 7-7.

https://doi.org/10.7202/1081881ar

All Rights Reserved ( C Canadian Science and Technology Historical Association / Ce document est protégé par la loi sur le droit d'auteur. L’utilisation des Association pour l'histoire de la science et de la technologie au Canada, 1979 services d’Érudit (y compris la reproduction) est assujettie à sa politique d'utilisation que vous pouvez consulter en ligne.

https://apropos.erudit.org/fr/usagers/politique-dutilisation/ 
Exploration :

Basil Greenhill, James Cook: The Opening of the Pacific (Palo Alto: Pendragon, 1978).

Medicine:

Estella Kennedy, "Immigrants, Cholera and the Saint John Sisters of Charity, 1854-64," Cdn. Cath. Hist. Assn, Study Sessions 44 (1977), 25-44

J.R. Porter, "L'Hôpital-Général de Québec et le soin des aliénés (1717-1845)," Soc. can. d'hist. Egl. Cath. Sessions d'étude 44 (197y), 23-55.

H.J. Alderson, Twenty-Five Years A-Growing: The History of the School of Nursing, McMaster University (Hamilton: McM. Univ., 1976).

Social:

W.W. Judd, ed. Minutes of the London Mechanics' Institute, 1841-1895 (London: London Public Libraries, 1976).

Transport:

K. Matthews \& G. Panting eds. Ships and Shipbuilding in the North Atlantic Region; ProC.....Mar 31-Apr 2, 1977 st. John's, Atlantic Can. Shipping Project (St. John's : Memorial Univ. 1978).

R. Fortin \& A. Lepiné, Bateaux et épaves du Richlieu (SaintJean-sur-Richlieu: Editions Milles Roches, 1978).

The editors would like to thank the following people for their generous contributions to the HSTC Bulletin:

$\begin{array}{lll}\text { Frances Anderson } & \text { A. W. Tickner } & \text { Marsha Snyder } \\ \text { Donald MacLeod } & \text { Andrew Wilson }\end{array}$

\section{AUTOBIOGRAPHY OF JOHN MACOUN}

The ottawa Field-Naturalists $c l u b$ is publishing a second edition of the Autobiography of John Macoun, edited by W.A. Waiser with an introduction by Richard Glover. The book should be available in September 1979. Further information can be obtained from:

The Ottawa Field-Naturalists Club, Box 3264, Station ' $C$ '

Ottawa, Ont. KIY 4 J5 